\title{
STUDY ON PHASE TRANSITION FEATURES AND INFRARED SPECTROSCOPY OF 3OCB LIQUID CRYSTAL
}

\author{
Atilla Eren MAMUK, Department of Physics, Faculty of Science, Muğla Sitkı Koçman University, aemamuk@mu.edu.tr
} (iD) https://orcid.org/0000-0002-1524-3342)

Received: 24.04.2021, Accepted: 10.08.2021

Research Article

*Corresponding author

DOI: $10.22531 /$ muglajsci.926980

\begin{abstract}
In the study, some physical properties of the 3OCB liquid crystal belonging to the cyanobiphenyl group, which is frequently used in dimeric molecules and eutectic mixtures, were investigated. In this context, its optical properties in different temperature interval have been investigated. As a result of optical measurements, it was determined that 30CB exhibited a monotropic mesophase and that the phase range of the mesophase was determined. In addition, it was observed that a heterophase region appeared in the liquid crystalline isotropic phase-nematic mesophase transition. Morphological analysis of the mesophase and heterophase region was also performed. Also, by performing calorimetric measurements, how the relevant liquid crystal phase interval changes in bulk state was compared with the results obtained from optical measurements. Information about the 30CB's dominant vibration bands was obtained by performing infrared spectroscopic measurements. The infrared spectroscopy of $30 \mathrm{CB}$, which is frequently used in industry and scientific studies, has been performed to provide information about the functional groups and structure of the molecule.
\end{abstract}

Keywords: Liquid crystals, Monotropic mesophase, Optic, DSC, FT-IR

\section{CB SIVI KRİSTALİNIN FAZ GEÇİŞ ÖZELLİKLERİ VE KIZILÖTESİ SPEKTROSKOPİSI ÜZERİNE ÇALIŞMA}

\section{Özet}

Çalışmada dimerik yapıda moleküllerde ve ötektik karışımlarda sıklıkla kullanılmakta olan siyanobifenil gurubuna ait 3OCB sıvı kristalinin bazı fiziksel özellikleri incelenmiştir. Bu bağlamda, farklı sıcaklık bölgelerinde optik özellikleri incelenmiştir. Optik ölçümler sonucu 30CB'nin monotropik mezofaz sergilediği tespit edilmiștir ve söz konusu mezofazın faz aralığı belirlenmiștir. Bununla birlikte, sıvı kristalin izotropik faz-nematik mezofaz geçiş bölgesinde heterofaz alanı ortaya çıktığı gözlenmiştir. Mezofaz bölgesinin ve heterofaz alanının morfolojik analizi de gerçekleștirilmiştir. Ayrıca, kalorimetrik ölçümler gerçekleştirilerek yığın halde ilgili sıvı kristalin faz araliğının nasıl değiștiği optik ölçümlerden elde edilen sonuçlar ile kıyaslanmıştır. Kızılötesi spektroskopik ölçümler gerçekleştirilerek 30CB'nin baskın titreşim bantları hakkında bilgiler edinilmiștir. Endüstride ve bilimsel çalışmalarda sıklıkla kullanılan 30CB'nin kızılötesi spektroskopisi gerçekleștirilerek molekülün fonksiyonel gurupları ve yapısı hakkında bilgi edinilmesi sağlanmıştır.

Anahtar Kelimeler: SIvı kristaller, Monotropik meofaz, Optik, DSC, FT-IR

Cite

Mamuk, A. E., (2021). “Study on Phase Transition Features and Infrared Spectroscopy of 3ocb Liquid Crystal”, Mugla Journal of Science and Technology, 7(2), 18-23.

\section{Introduction}

Liquid crystals are widely used in display technologies and optical devices. They consist of rod-like molecules that tend to orient along a common direction vector due to external fields such as surface interactions and electric fields [1]. Liquid crystals generally exhibit several mesophases that differ according to the order of the molecules and the dynamics of these molecules are affected by the transition from one phase to another [2]. In the nematic $(\mathrm{N})$ mesophase there is a weak orientational order and the molecules are arranged on average along one directional vector. However, there are many mesophases of different molecular order and orientation [3]. Nowadays, thousands of organic compounds are known to form liquid crystals. For mesomorphism to occur, it is essential that the molecule be geometrically highly anisotropic. These crystalline molecules exhibit a high degree of long-range orientational order in addition to their long-range translational order. At the melting temperature, molecules with anisotropic nature tend to maintain a parallel orientation, even if they are free to flow. When only this orientational order exists, the phase is called the 
nematic liquid crystal. In a significant number of mesogenic organic compounds, the liquid-crystalline phases are monotropic, i.e., they form from the supercooled dilution with random organization only at cooling below the melting point. For technical applications, eutectic mixing systems of mesogenic compounds are also used together with eutectic (selfsoluble) mixture due to their wide mesomorphic range [4]. Liquid crystals with monotropic mesophase are especially used to obtain new eutectic liquid crystal mixtures with wide temperature range and liquid crystal with side chain discotic-columnar molecular structure [5-8]. However, monotropic liquid crystals are used to form some dimeric molecules, called twist-bend nematic phase, which consists of two mesogenic structures combined with a flexible separator [9-13]. The 4propoxy-biphenyl-4-carbonitrile (30CB) monotropic nematic liquid crystal is a liquid crystal belonging to the 4-alkoxy-4-cyanobiphenyls (mOCBs). Molecules in this structure have long chain aliphatic compounds. Liquid crystals of mOCBs are commercially available and are widely used both in industry and in scientific studies due to their low melting point. The general feature of members of the mOCBs family is that they have two highly polarizable aromatic rings with cyano and alkyl groups at their ends [14-18]. Nematic liquid crystal mesophase has the simplest liquid crystalline structure and exhibits weak orientational order. The results of studies on nematic phases also provide an advantage for understanding the dynamics of molecules in other mesophases. Examination of optical, spectroscopic and calorimetric properties of 30CB liquid crystal will give information about potential eutectic mixtures and dimeric molecules containing monotropic liquid crystals. In this study, by examining the textures, the optical properties and phase transition temperatures of the 30CB were investigated in order to obtain information of these structures. In addition, the behavior of phase transition temperatures in heating and cooling processes was investigated by calorimetric measurement. Information about the chemical processes and structures of the material was obtained by performing infrared spectroscopy.

\section{Material and Method}

The nematic liquid crystal material examined in this study (30CB) was obtained from TCI Inc. company. The phase transition temperatures and textures of the sample were determined using an Olympus BX-51P polarization microscope (POM). The 30CB liquid crystal was first filled with a capillary effect into unoriented smooth glass cells of approximately $10 \mu \mathrm{m}$ thickness. These cells were placed between crossed polarizers and phase transition temperatures were determined by taking the relevant textures. During cooling, the sample exhibited the monotropic nematic phase between $67.9^{\circ} \mathrm{C}$ and $57.2^{\circ} \mathrm{C}$, and during heating it passed to the isotropic phase at a temperature of $74.5^{\circ} \mathrm{C}$. Differential Scanning Calorimetry (DSC) measurements were performed with
Perkin Elmer DSC 8000 model device. With this measurement, phase transition characteristics of the liquid crystal were determined depending on the temperature. The liquid crystal sample was placed in an aluminum container. In order to be the reference weight in the measurements, the weight of the empty container was measured and the its value was found to be 0.002 mg. The thermal scanning range was set at approximately $0{ }^{\circ} \mathrm{C}$ to $105^{\circ} \mathrm{C}$. In this temperature range, measurement was carried out with a scanning speed of $5{ }^{\circ} \mathrm{C} /$ minute. Scanning was carried out in nitrogen gas environment with a flow rate of $20 \mathrm{ml} / \mathrm{min}$. The liquid crystal was first cooled to $0{ }^{\circ} \mathrm{C}$ and kept at this temperature for 10 minutes. Afterwards, the scanning process continued until the target temperature of $105^{\circ} \mathrm{C}$ was reached with constant scanning speed. When the target temperature was reached, the cooling process was started and the scanning process was continued until the starting temperature, $0{ }^{\circ} \mathrm{C}$, was reached. Fourier Transform Infrared (FT-IR) spectroscopy of the studied sample was performed between $400 \mathrm{~cm}^{-1}$ and $4000 \mathrm{~cm}^{-1}$ at room temperature $\left(27^{\circ} \mathrm{C}\right)$ using a Perkin-Elmer spectrometer (equipped with Universal ATR sampling accessory).

\section{Results}

For identification of liquid crystal phases the most widely used technique is the POM technique which has the ability to show each liquid crystal phase with a distinct optical texture [3]. Under POM, the material does not exhibit any optical transmittance, i.e. only a black image is detected in the ocular, which corresponds to the isotropic phase for liquid crystals. The polarization state of linearly polarized incident light coming into the liquid crystal between the cross polarizers changes after passing through the liquid crystal and becomes elliptical polarized. Because elliptically polarized light has a component that can pass through the analyzer, it appears bright when viewed through the liquid crystal POM [19]. In Figure 1, the textures of the 30CB liquid crystal obtained in different phases and during phase transitions are given. Scale bar corresponds to $100 \mu \mathrm{m}$. In order to obtain the textures, the 30CB liquid crystal was first heated up to the isotropic phase. Afterwards, the temperature was decreased. When the temperature reaches approximately $67.9{ }^{\circ} \mathrm{C}$, an isotropic-nematic (I-N) phase transition has been observed and this transition is shown in Figure 1a. The right side of the texture is completely black and this region corresponds to the isotropic phase. The left side shows interference colors due to the random arrangement of the liquid crystal molecules. The azimuth angle of the liquid crystal molecules with respect to the polarizer and the analyzer constitutes the phase difference between ordinary and extraordinary waves. Due to this phase difference, interference colors occur in the mesophase region [19]. Figure $1 \mathrm{~b}$ shows the texture of the nematic mesophase of the 30CB liquid crystal. This texture was obtained at a temperature of $62^{\circ} \mathrm{C}$. It is a Schlieren type texture, which 
is a typical texture for the nematic mesophase. Schlieren textures generally exhibit characteristic dark brush defect sets. If one looks carefully, it is noticed that these defects come together at a single point and can be twoor four-way. Singularities are topological defects having a specific power [19]. With further cooling of the sample, it is clearly seen that it passes to the solid crystal phase (K) (Figure 1c). While the colored region in the right-upper part of the texture is the typical appearance of the $\mathrm{N}$ mesophase, the dark colored region seen in the left-bottom part is the appearance of the $\mathrm{K}$ phase. This texture was obtained at a temperature of approximately $57.2{ }^{\circ} \mathrm{C}$. After the transition to the $\mathrm{K}$ phase, 30CB molecules became more organized and started to form domain structures. After waiting for sufficient time in the $\mathrm{K}$ phase, the sample was started to be heated again. During the heating process, the nematic mesophase seen during the cooling process was not determined. When the sample temperature reaches $74.5^{\circ} \mathrm{C}$, the transition from phase $\mathrm{K}$ to phase I took place (Figure 1d). This situation is expected for monotropic liquid crystals $[4,5,20]$.
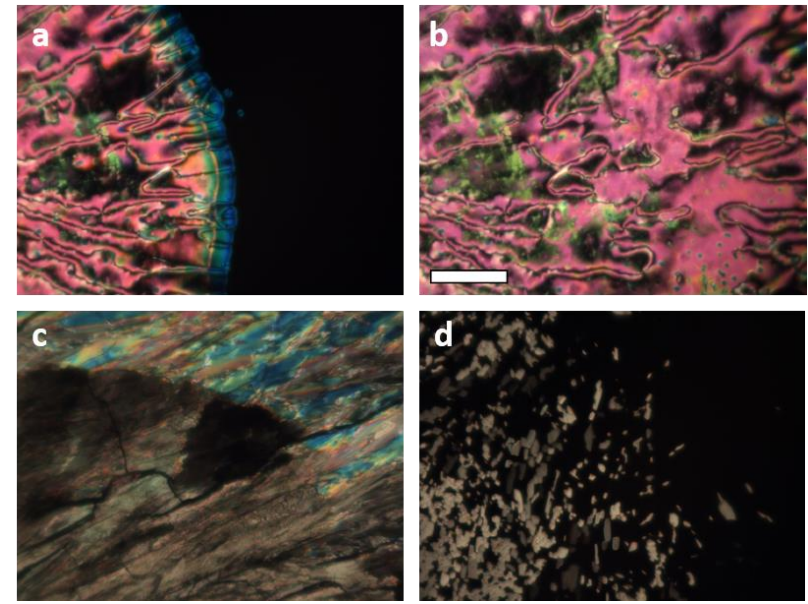

Figure 1. The phase transition and mesophase textures of the 30CB liquid crystal material. (a) I-N phase transition, (b) nematic mesophase, (c) N-K phase transition, (d) K-I phase transition. Scale bar corresponds to $100 \mu \mathrm{m}$ length.

During the I-N phase transition, a heterophase region of approximately $50 \mu \mathrm{m}$ width was revealed (Figure 2 ). The I-N phase transition is a weak first order transition, as the order parameter changes discontinuously and the latent heat is approximately $10 \mathrm{~J} / \mathrm{g}$ in the I-N phase transition. The I- $\mathrm{N}$ phase transition is described by Landau-De Gennes theory and the free energy density of a liquid crystal can be expanded in terms of an order parameter. With the Landau-De Gennes theory, the regions of I phase and $\mathrm{N}$ mesophase where are stable and unstable are defined in the heterophase area, i.e. very close to the phase transition temperature (at the boundaries of the heterophase area) [1,3,21-23]. Stripes of different colors have been determined in the heterophase region. This color difference indicates a liquid crystalline phase directly related lamination in the heterophase area. In addition, defects in the form of inversion walls and singularities were formed similar to the nematic mesophase texture. Such defects are usually seen in thick cells. The width of the heterophase field varies depending on the cell thickness and different chemical groups in the liquid crystal molecular structure [24,25].

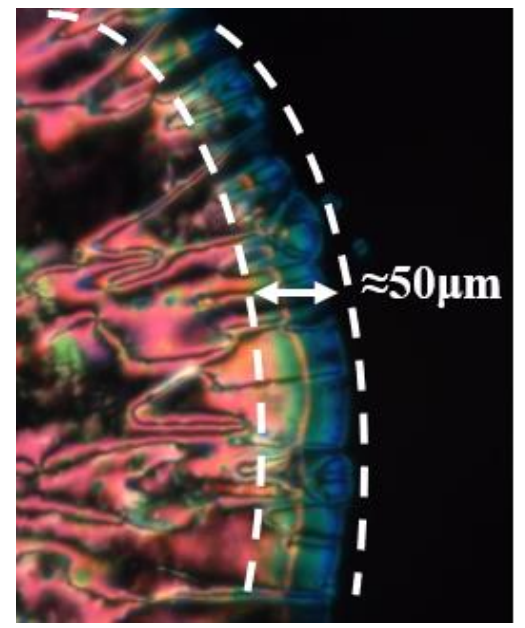

Figure 2. The texture of the heterophase region in I-N phase transition.

In this study, the calorimetric measurement of the 30CB liquid crystal was carried out in the heating and cooling processes. The results obtained with optical microscopy can be generally supported by DSC measurements. With this technique, the presence of mesophase and liquid crystal phases can be revealed by detecting the enthalpy change related to phase transition. This technique alone is not sufficient in defining the type of liquid crystal phase. However, the level of enthalpy change provides some information about the degree of molecular order within a mesophase $[3,21,26,27]$. Figure 3 shows the thermo-graph of the 30CB liquid crystal. The curve labeled in red gives the scanning results during the heating from the solid crystal phase to the isotropic phase. While heating the sample, a high peak occurred at about $79.2^{\circ} \mathrm{C}$, as clearly observed in the thermo-graph. This peak corresponds to a strong first order K-I phase transition. Such high enthalpy peaks observed in DSC thermo-graphs are usually the transition peaks of the $\mathrm{K}$ phase. The peaks of liquid crystalline mesophase transitions or I phase transitions are significantly smaller, indicating weak first-order transition [21]. After the scanning process was completed during heating, the sample was cooled in the same temperature range (approximately $0{ }^{\circ} \mathrm{C}-105^{\circ} \mathrm{C}$ ) and the scanning process was carried out (Figure 3, blue curve). I-N phase transition peak was observed at a temperature of about $67.1{ }^{\circ} \mathrm{C}$. As expected, this peak indicates a very small enthalpy value, unlike the high peaks observed in $\mathrm{K}$ phase transitions and shows a weak first order phase transition. With the resuming the cooling process, the $\mathrm{N}-\mathrm{K}$ phase transition peak was detected at a temperature of about $57.4{ }^{\circ} \mathrm{C}$. As expected, the $\mathrm{N}-\mathrm{K}$ peak has a high enthalpy value as the K-I peak and gives a strong first order phase transition. Table 1 shows the values of phase 
transition temperatures obtained in POM and DSC measurements. In addition, the enthalpy values of the phase transition peaks observed in the DSC thermograph are also shown in the same table. The difference between the phase transition temperatures obtained as a result of DSC and POM measurements was determined. In the measurements performed with POM, the 30CB liquid crystal was examined in a non-oriented smooth glass cell with a thickness of approximately $10 \mu \mathrm{m}$. In DSC measurements, liquid crystal was used in bulk state. There is a high anchoring effect in the liquid crystal examined in glass cells. This effect is particularly effective in mesophase transitions. This effect is quite low in liquid crystals measured in bulk. Therefore, the measurement conditions of liquid crystal can shift the phase transition temperatures and mesophase intervals [28]. The reason why I-N phase transition temperature is approximately $0.8{ }^{\circ} \mathrm{C}$ higher in POM measurement than DSC measurement is the requirement for higher energy for phase transition with high anchoring effect.

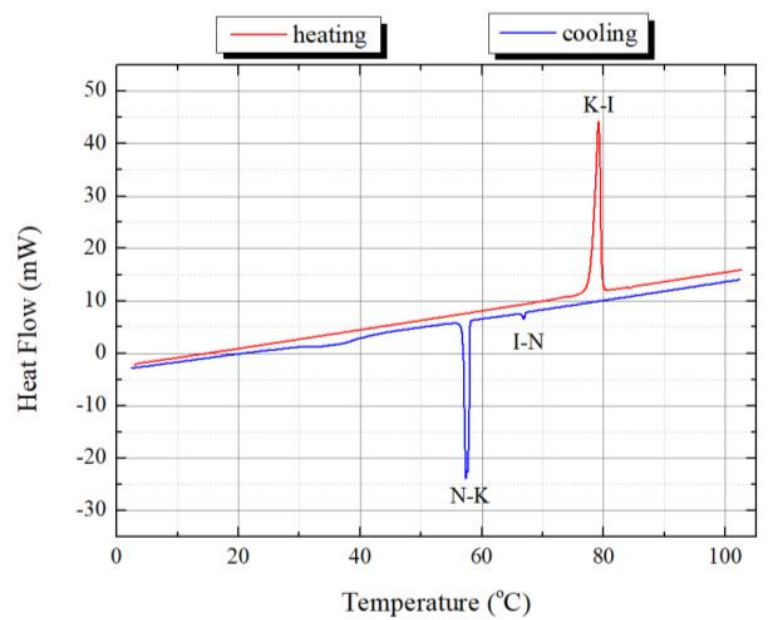

Figure 3. The DSC thermo-graph of 30CB. Scanning rate was $5{ }^{\circ} \mathrm{C} / \mathrm{min}$. The red and blue curves correspond to heating and cooling process, respectively.

Table 1. The phase transition temperatures and enthalpies of 30CB.

\begin{tabular}{cccc}
\hline $\begin{array}{c}\text { Phase } \\
\text { Transition }\end{array}$ & $\begin{array}{c}\text { Phase } \\
\text { Transition } \\
\text { Temperature } \\
(\mathbf{P O M}), \mathbf{T}_{\mathbf{x y}} \\
\left({ }^{\circ} \mathbf{C}\right)\end{array}$ & $\begin{array}{c}\text { Phase } \\
\text { Transition } \\
\text { Temperature } \\
\text { (DSC), } \mathbf{T}_{\mathbf{x y}} \\
\left({ }^{\circ} \mathbf{C}\right)\end{array}$ & $\begin{array}{c}\text { Enthalpy, } \\
\boldsymbol{\Delta H}(\mathrm{J} / \mathrm{g})\end{array}$ \\
\hline $\boldsymbol{K}-\boldsymbol{I}$ & 74,5 & 79,2 & 7,718 \\
\hline $\boldsymbol{I}-\boldsymbol{N}$ & 67,9 & 67,1 & 0,113 \\
\hline $\boldsymbol{N}-\boldsymbol{K}$ & 57,2 & 57,4 & 4,962 \\
\hline
\end{tabular}

Using Fourier Transform Infrared (FT-IR) spectroscopy to map the short-range interactions between various structural components in liquid crystals is an effective method to study and optimize the molecular architecture of liquid crystals for applications such as electrolyte membranes. The number, distribution, and position of charged or polar groups largely determine the physicochemical and conductivity properties of these materials [29]. However, temperature dependent FT-IR spectroscopy is widely used to understand the mechanism of phase transitions in liquid crystals at the molecular level. The zone of spectroscopy which is socalled fingerprint is very informative about structural changes and provides specific information about the nuclei (phenyl rings) and linking groups (azo, ester, imine) or functional groups (hydroxyl or H-bonds) of liquid crystals. The position, height and width of the peaks that provide information about chemical bonds and groups are sensitive to temperature, so they are also used to investigate the dynamics of the molecule during phase transition [30-32]. In Figure 4, the transmittance curve of the 30CB liquid crystalline FT-IR spectroscopy performed at room temperature is given.

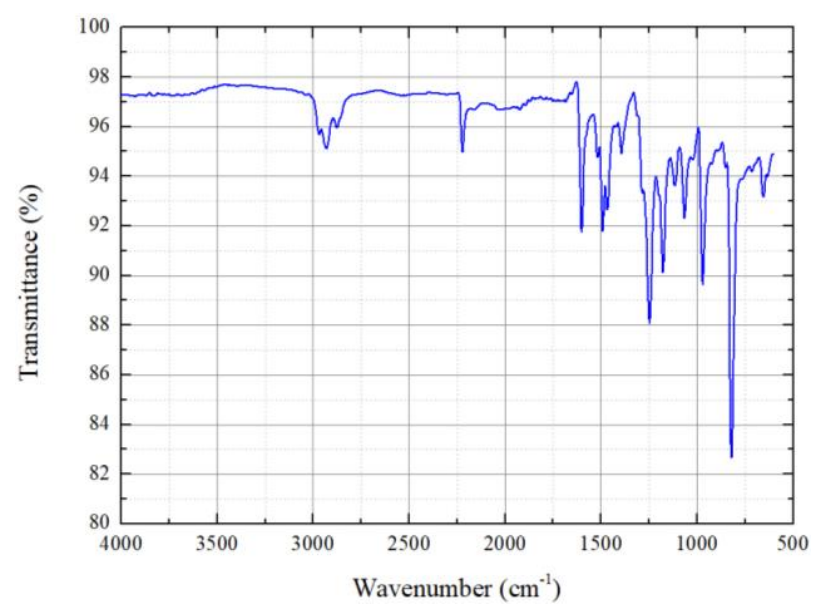

Figure 4. The FT-IR spectroscopy of 30CB.

In addition, the summary of the main vibration bands of the 30CB liquid crystal detected in Figure 4 is given in Table 2. The 30CB molecule consists of a propoxy group at one end and a $\mathrm{C} \equiv \mathrm{N}$ group at the other. When the vibrations of spectroscopy are examined, existing of such vibration modes including the $\mathrm{CH}$ stretching modes of the $\mathrm{CH}_{3}, \mathrm{C}=\mathrm{C}$ stretching modes, $\mathrm{CH}_{3}$ deformations and $\mathrm{H}-\mathrm{C}-\mathrm{C}$ bending modes are determined. The transition moment of the $C \equiv N$ stretch vibration is located in the direction of the long axis of the molecule. Therefore, molecular orientations on this axis do not contribute to the broadening of the band. Contributions of molecular orientations with respect to the other two axes are negligible [14]. The $C N$ group of a molecule of $30 C B$ is located on the $C-O$ group of other $30 C B$ molecules. Thus, the dipole moments of both 30CB molecules eliminate each other. Spectral bands corresponding to these vibrations are separated from neighboring bands. In addition, these bands are highly sensitive to changes in intermolecular interactions [16]. 
Table2. The summary of the main vibration bands

\begin{tabular}{cl}
\hline $\begin{array}{c}\text { Wavenumber } \\
\left(\mathrm{cm}^{-1}\right)\end{array}$ & Vibration Mode \\
\hline $\mathbf{2 9 5 8}$ & $\begin{array}{l}\text { Asymmetric } C H_{3} \text { stretch of alkyl } \\
\text { chain }\end{array}$ \\
\hline $\mathbf{2 9 2 9}$ & $\begin{array}{l}\text { Asymmetric } C H_{2} \text { stretch of alkyl } \\
\text { chain }\end{array}$ \\
\hline $\mathbf{2 8 7 1}$ & Symmetric $C H_{3}$ stretch of alkyl chain \\
\hline $\mathbf{2 8 5 9}$ & Symmetric $C H_{2}$ stretch of alkyl chain \\
\hline $\mathbf{2 2 2 0 , 1}$ & $C \equiv N$ stretching \\
\hline $\mathbf{1 6 0 0 , 7}$ & Stretching of $C=C$ of phenyl ring \\
\hline $\mathbf{1 5 7 6 , 5}$ & Stretching of $C=C$ of phenyl ring \\
\hline $\mathbf{1 4 9 6 , 5}$ & Stretching of $C=C$ of phenyl ring \\
\hline $\mathbf{1 3 9 2 , 9}$ & Bending of $C H_{2}$ of alkyl chain \\
\hline $\mathbf{1 2 4 6 , 7}$ & Stretching of $C=C$ of phenyl ring \\
\hline $\mathbf{1 1 7 6 , 6}$ & Stretching of $C-H$ of phenyl ring \\
\hline $\mathbf{1 1 1 5}$ & $\begin{array}{l}\text { Stretching of } C-C \text { of hydrocarbon } \\
\text { and } C H_{2} \text { bending }\end{array}$ \\
\hline $\mathbf{1 0 6 4}$ & Asymmetric stretching of $C$ - $O-C$ \\
\hline $\mathbf{9 2 9 , 8}$ & $C H_{2}$ rocking \\
\hline $\mathbf{8 2 0 , 4}$ & $\begin{array}{l}C-H \text { of phenyl ring out of plane } \\
\text { bending }\end{array}$ \\
\hline $\mathbf{6 5 3 , 9}$ & $\begin{array}{l}C-C \text { of phenyl ring in plane } \\
\text { bending }\end{array}$ \\
\hline
\end{tabular}

\section{Conclusion}

In this study, optical, calorimetric and infrared spectroscopic measurements of the 30CB liquid crystal were performed. As a result of optical measurements, it has been determined that the liquid crystal exhibited a monotropic behavior. In addition, information about the morphology of the sample was obtained by examining the textures. A relatively large heterophase area was revealed in the I-N phase transition region. The different colored formations in this region and laying parallel to each other show that a structure with different orientation degrees belonging to unstable $\mathrm{N}$ phases was formed in the heterophase region. In addition, it was found that inversion walls and singularities clearly observed in the $\mathrm{N}$ mesophase region extend to the heterophase region. As a result of the calorimetric measurements of the 30CB liquid crystal, very high $\mathrm{K}$ phase transition peaks were determined in both heating and cooling processes. During heating, no transition peak was observed except for the K-I phase transition peak. During cooling, a very small peak was detected compared to the $\mathrm{K}$ phase transition peak. This peak corresponds to the I-N phase transition and indicates a weak first order phase transition. It was determined that there was some difference between the phase transition temperatures obtained in optical and calorimetric measurements. This difference was interpreted as that the liquid crystal in the form of a thin film sandwiched between the surfaces was exposed to a higher anchoring effect than the bulk liquid crystal. In the study, infrared spectroscopy of the 30CB liquid crystal was also studied. Chemical bonds and groups corresponding to the transmittance peaks of the molecule were identified in the measurements. These defined structures will be very useful in understanding the dielectric and structural properties of new dimeric liquid crystal molecules and various liquid crystal mixtures to be synthesized using 30CB liquid crystals.

\section{Acknowledgement}

The author would like to acknowledge the technical support of The Center of Research Laboratories, Muğla Sıtkı Koçman University.

\section{References}

[1] Oswald, P. and Pieranski, P. Smectic and Columnar Liquid Crystals, Taylor \& Francis, Boca Raton, 711s., 2005.

[2] Demus, D., Goodby, J., Gray, G.W., Spiess, H. -W., and Vill, V., Handbook of Liquid Crystals, WileyVCH, Weinheim, 2591s. 1998.

[3] Collings, P.J. and Hird, M., Introduction to liquid crystals: Chemistry and physics, Taylor \& Francis, London, 317s., 2017

[4] Onusseit, H Stegmeyer, H. "Investigations Of Phase Diagrams with Monotropic LiquidCrystalline Phases", Thermochimica Acta, 83, 145-152, 1985.

[5] Onusseit, H. and Stegemeyer, H., "Phase Diagrams of Eutectic Mixed Systems with Monotropic Liquid-Crystalline Phases", Molecular Crystals and Liquid Crystals. 111 (1-2), 31-43., 1984.

[6] Jungbauer, D. and Wendorff, J.H., "Electro-Optical Studies on Monotropic Nematic-Smectic Phase Transitions", Molecular Crystals and Liquid Crystals Incorporating Nonlinear Optics, 170 (1), 159-177, 1989.

[7] Šakalyte, A., Giamberini, M., and Reina, J.A., "Synthesis and characterisation of a monotropic dendritic liquid crystalline aziridine monomer", Liquid Crystals. 41 (2), 153-162, 2014.

[8] Ahmed, H.A. "Mesophase stability in binary mixtures of monotropic nematogens", Liquid Crystals. 42 (1), 70-80, 2015.

[9] Grunwald, M.A., Haenle, J.C., Kreß, K.C., Forschner, R., Wöhrle, T., Frey, W., et al. "Mesomorphic properties of cyanobiphenyl dimers with a central malonate unit", Liquid Crystals, 45(11), 1626-1636, 2018.

[10] Paterson, D.A., Crawford, C.A., Pociecha, D., Walker, R., Storey, J.M.D., Gorecka, E., et al., "The role of a terminal chain in promoting the twistbend nematic phase: the synthesis and characterisation of the 1-(4-cyanobiphenyl-4'yl)-6-(4-alkyloxyanilinebenzylidene-4'oxy)hexanes", Liquid Crystals, 45(13-15), 2341- 
2351, 2018.

[11] Wang, K., Jirka, M., Rai, P., Twieg, R.J., Szilvási, T., $\mathrm{Yu}, \mathrm{H}$., et al., "Synthesis and properties of hydroxy tail-terminated cyanobiphenyl liquid crystals", Liquid Crystals, 46(3), 397-407, 2019.

[12] Wang, K., Rai, P., Fernando, A., Szilvási, T., Yu, H., Abbott, N.L., et al., "Synthesis and properties of fluorine tail-terminated cyanobiphenyls and terphenyls for chemoresponsive liquid crystals", Liquid Crystals, 47(1), 3-16, 2020.

[13] Paterson, D.A., Abberley, J.P., Harrison, W.T.A., Storey, J., and Imrie, C.T., "Cyanobiphenyl-based liquid crystal dimers and the twist-bend nematic phase", Liquid Crystals, 44(1), 127-146, 2017.

[14] Sharma, D. and Nath Tiwari, S., "Molecular Structure and Vibrational Dynamics Studies of 4n-propyl-4'-cyanobiphenyl using $\mathrm{Ab}$ initio and DFT Methods", Materials Today: Proceedings. 5 (7), 15325-15334, 2018.

[15] Babkov, L.M., Davydova, N.I., Puchkovskaya, G.A., and Khakimov, I.N., "IR absorption spectra and structure of 4-cyano-4',-p-alkoxybiphenyls", Journal of Structural Chemistry, 34, 92-97, 1993.

[16] Sharma, D., Tiwari, G., and Tiwari, S.N., "Thermodynamical properties and infrared spectra of 4-n-propoxy-4'- cyanobiphenyl: Hartree-Fock and density functional theory methods", International Journal of Electroactive Materials, 5 (2), 19-30, 2017.

[17] Giricheva, N.I., Fedorov, M.S., Shpilevaya, K.E., Syrbu, S.A., and Ditsina, O.Y., "Characteristics of the hydrogen bond and the structure of $\mathrm{H}$ complexes of p-n-propyloxybenzoic acid and p-npropyloxy-p'-cyanobiphenyl", Journal of Structural Chemistry, 58 (1), 9-16, 2017.

[18] Kuz'mina, L.G., Kucherepa, N.S., and Churakov, A. V., "Mesophase design: II. Molecular structure and crystal packing of 4alkyloxycyanobiphenyls", Crystallography Reports, 57 (2), 213-226, 2012.

[19] Dierking, I., Textures of Liquid Crystals, WILEYVCH Verlag GmbH\&Co. KGaA, Weinheim, 233s, 2003.

[20] Różycka, A., Deptuch, A., Jaworska-Gołąb, T., Węgłowska, D., and Marzec, M., "Evidence of monotropic hexatic tilted smectic phase in the phase sequence of ferroelectric liquid crystal" Phase Transitions, 91 (2), 159-169, 2018.

[21] Blinov, L.M., Structure and Properties of Liquid Crystals, Springer, Dordrecht, Heidelberg, London, New York, 458s, 2011.

[22] Doi, M. Soft Matter Physics, Oxford University Press. Oxford, 270s, 2013.
[23] Kleman, M. and Lavrentovich, O.D., Soft Matter Physics: An Introduction, Springer New York, New York, NY, 664s, Eds. 2004.

[24] Mamuk, A.E. and Nesrullajev, A., "Peculiarities of thermo-morphologic and thermotropic transformations of heterophase regions: nematic $\leftrightarrow$ isotropic phase transition in 4-n-Alkyl-4'cyanobiphenyl mesogens", Journal of Optoelectronics and Advanced Materials. 21 (1112), 691-697, 2019.

[25] Nesrullajev, A., Avci, N., and Oktik, S., "Peculiarities of biphasic regions at phase transitions in oriented textures of 4-cyano-4'-npentylbiphenyl", Physics Letters, Section A: General, Atomic and Solid State Physics, 364 (6), 510-514, 2007.

[26] Smith, G.W., "Study of Formation, Phase Behavior, and Microdroplet Size of a Polyurethane-based Polymer-dispersed Liquid Crystal", Molecular Crystals and Liquid Crystals Incorporating Nonlinear Optics, 180 (2), 201-222, 1990.

[27] Smith, G.W. and Vaz, N.A., "The relationship between formation kinetics and microdroplet size of epoxy-based polymer-dispersed liquid crystals", Liquid Crystals, 3 (5), 543-571, 1988.

[28] Alexe-Ionescu, A.L., Barberi, R., Bonvent, J.J., and Giocondo, M., "Nematic surface transitions induced by anchoring competition", Physical Review E - Statistical Physics, Plasmas, Fluids, and Related Interdisciplinary Topics, 54 (1), 529-535, 1996.

[29] Martínez-Felipe, A., Imrie, C.T., and Ribes-Greus, A., "Study of structure formation in side-chain liquid crystal copolymers by variable temperature fourier transform infrared spectroscopy", Industrial and Engineering Chemistry Research, 52 (26), 8714-8721, 2013.

[30] Singh, S., Singh, H., Srivastava, A., Tandon, P., Deb, R., Debnath, S., et al., "Study of phase transitions in a bent-core liquid crystal probed by infrared spectroscopy", Vibrational Spectroscopy, 86, 2434., 2016.

[31] Osiecka, N., Galewski, Z., Juszyńska-Gałązka, E., and Massalska-Arodź, M., "Studies of reorganization of the molecules during smectic A-smectic C phase transition using infrared spectroscopy and generalized two-dimensional correlation analysis", Journal of Molecular Liquids, 224, 677-683, 2016.

[32] Avadanei, M., Perju, E., Cozan, V., and Bruma, M., "Phase transitions of a monotropic azomethine liquid crystal investigated by ATR-FTIR spectroscopy", Phase Transitions, 87 (3), 243254, 2014. 